Gut, 1967, 8, 8

\title{
Eosinophilic granuloma of the gastro-intestinal tract
}

\author{
P. R. SALMON ${ }^{1}$ AND J. W. PAULLEY \\ From Princess Margaret Hospital, Swindon, Wiltshire and \\ Ipswich and East Suffolk Hospital, Ipswich, Suffolk
}

EDITORIAL COMMENT This paper presents a comprehensive review of eosinophilic granuloma of the alimentary tract. The view is put forward that eosinophilic granulomas mainly represent part of a systemic allergic response to one of a number of non-specific allergens. Steroids may be of real value in treatment.

The first specific reference to an eosinophilic granuloma of the bowel was that of Mock (1931) who, in a discussion of infective granuloma, drew attention to a pyloric lesion, possibly eosinophilic. Kaijser (1937) described the first cases, of which one patient, who had been allergic to onions since youth, developed an eosinophilic granuloma of the pyloric antrum. The others, both syphilitics, who were allergic to neoarsphenamine, developed jejunal lesions. These cases assumed greater interest because in the same year two papers appeared showing the effect of allergens on the gastrointestinal tract (Hansen and Simonsen, 1937; Afendoulis and Gulzöw, 1937). Later Afendoulis (1943) reported two instances of drug allergy associated with gastritis and a further example of allergic gastritis following ingestion of cheese.

Harkavy (1941) in an article entitled 'Pathogenesis of bronchial asthma with recurrent pulmonary infiltration and eosinophilic polyserositis' described eight cases of bronchial asthma. Six had eosinophilic sterile pleural effusions and three peritoneal involvement with eosinophilic ascites. Others had pericardial involvement. The peripheral eosinophil count ranged from 12 to $84 \%$. Angioneurotic oedema occurred twice and polyarteritis nodosa once. Harkavy concluded that all these patients showed an altered vascular response, indicating a common 'allergenic stimulation'. Most later contributors have mentioned allergy and concluded that hypersensitivity plays an important aetiological role.

A disturbance of oestrogen-progesterone metabolism was considered likely by Sison, Dionisio, Silva, and Chavez (1947), whilst Sherman and Moran (1954) felt that gastric granulomata were probably due to foreign-body reactions, and considered that the presence of eosinophils did not justify a diagnosis of eosinophilic granuloma nor an allergic aetiology.

Ashby, Appleton, and Dawson (1964) concluded ${ }^{1}$ Present Address: Department of Medicine, Bristol Royal Infirmary,
Bristol. that the majority of cases were due to a local gastrointestinal reaction secondary to repeated infestation by intestinal parasites, especially the 'herring worm' (Eustoma rotundatum) in the bowel. This followed the observation of Kuipers, van Thiel, and Roskam (1960a) Kuipers, van Thiel, Rodenburg, Wielinga, and Roskam (1960b) who reported 13 examples of localized intestinal granulomata associated with Eustoma.

It seems to us that previous arguments as to whether eosinophilic granuloma of the bowel is primarily a local phenomenon or part of a systemic allergic reaction may be irrelevant and dependent on the extent of the host response and the site and mode of allergic insult. For example, those in the pyloric antrum usually give rise to pyloric stenosis either directly or by prolapsing into the duodenum, whilst the primary infiltrative type involving any part of the bowel may be associated with a variety of systemic allergic conditions and high blood eosinophil counts.

In addition eosinophilic infiltration may give rise to a polyserositis (Harkavy, 1941; Salmon and Paulley, 1966) or involve the peritoneum only, causing eosinophilic ascites (Sison, Dionisio, Silva, and Chavez, 1947; Swarts and Young, 1955; Harley, Glushien, and Fisher, 1959), while other viscera may be involved, as in the case showing involvement of all the bowel, mesenteric nodes, ovaries, uterus, bladder, and heart (Fossgreen, 1962).

\section{CASE REPORTS}

CASE 1 J.E., a farmer, in 1949, when aged 26, was referred to one of us (J.W.P.) because of sudden attacks of indigestion and vomiting occurring regularly every two to three weeks. When first seen the attacks were usually preceded by swelling of the hands and arms, but several years previously he had had classical angioneurotic oedema of the face.

Past history included a Caldwell-Luc operation for persistent rhinorrhoea, and a barium meal and followthrough in 1943 for similar attacks of vomiting and 


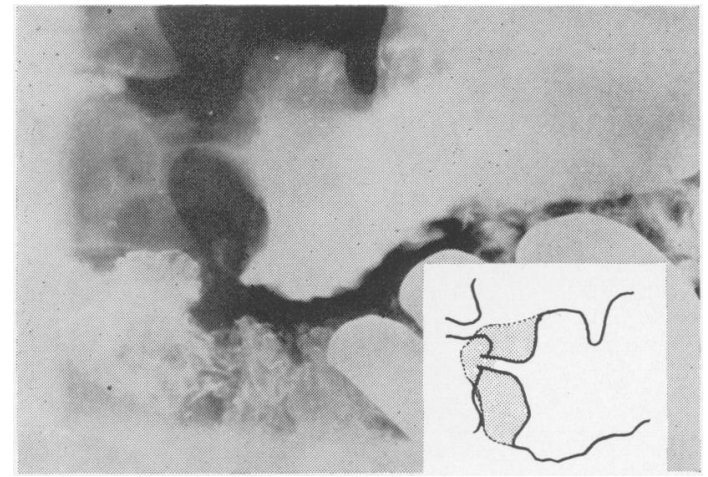

FIG. 1. Diagram (inset) showing filling defect in the prepyloric region ('shoulder sign').

indigestion. This showed intermittent pyloric spasm. Tenderness in the right iliac fossa had led to an appendicectomy which did not relieve his symptoms. He had never passed blood or slime.

There was no family history of allergy, but a sister had multiple sclerosis; three brothers were alive and well.

The patient was married with one daughter, and was obsessional about his work to the exclusion of all recreation. For two years he had been worried financially and was afflicted with insomnia.

The patient was a young man of asthenic build. The caecum was easily palpable and tender, further barium meal showed clumping of barium in the terminal ileum with some spasm or narrowing, and a diagnosis of ileocolitis (Crohn's disease) was considered. He was treated with barbiturates and antihistamines. In 1951 he was seen again because of a further bout of intermittent vomiting and lower abdominal pain. Because of the strong allergic history elimination diets were tried but without benefit. In 1953 he was still complaining of swelling of the lips, eyelids, and vomiting attacks about once a fortnight. He was admitted on 8 June, 1953.

Haemoglobin was $89 \%$, W.B.C.s $7,600 / \mathrm{mm}^{3}$ (eosinophils, $2 \%, 152 / \mathrm{mm}^{3}$ ). A barium meal (Fig. 1) reported by Dr. K. E. Barlow showed 'some hypotonicity with excess of resting juice. On the greater curve immediately proximal to the pylorus I became suspicious of a smooth round intramural mass. I consider the appearances sufficiently suspicious of a so-called innocent tumour to warrant exploration. ...' He was referred for a surgical opinion but exploratory laparotomy was not performed because the patient's symptoms improved and he wished to be discharged. He did not consult us again but his family say that his attacks continued at varying intervals.

On 27 June 1961, after a fair-sized lunch of roast chicken he suddenly became cyanosed and dyspnoeic and died.

Necropsy (Dr. A. B. Lintott) revealed gross oedema of the nasopharynx and larynx obstructing the trachea as the cause of death. The wall of the duodenum and gall bladder were oedematous and the gastric lining showed slight oedema. The pyloric antrum, apart from showing mucosal oedema, did not show an intramural mass as seen on the barium meal in 1953.
CASE 2 G.C., a man aged 36, an only child, had alopecia totalis since the age of 7 . In 1955 (aged 25) he was treated for intermittent vomiting which soon cleared up. In 1957, he presented with vomiting and colicky central abdominal pain for three weeks. Vomiting partly relieved the pain. He then developed swelling of the abdomen, and passed four or five loose motions daily without visible blood or mucus. His appetite was unimpaired. There was a past history of repeated vomiting in the first week of life, and for his first 18 months he was under medical supervision because of vomiting and failure to thrive. There was no known family history of allergy or food intolerance, but he said he was greatly affected by dust; however, he did not change his job driving an excavator. He seemed young for his age, shy, friendless, emotionally detached and supine. He lived with his mother with whom he had an intense relationship. She did everything for him and was generally protective towards him. He said his hair fell out at age of 7 when he went to school which he hated. It became clear that he was inclined to brood and avoided any form of rebuff by a submissive smiling and placatory attitude. His attitude epitomized conformity; he spoke in platitudes, and he was sensitive to the most subtle expression of hostility.

On admission on 15 July 1957 there was tense ascites and oedema of the anterior abdominal wall, and bilateral hydrothorax. He had alopecia totalis.

Haemoglobin was $106 \%$, E.S.R. (Westergren) $1 \mathrm{~mm}$. in the first hour. A chest radiograph showed bilateral basal effusions, and a film of the abdomen with the patient erect showed a distended small bowel with a few fluid levels.

Liver function tests were normal. W.B.C.s on 2 August were $7,800 / \mathrm{mm}^{3}{ }^{3}$ (eosinophils $28 \%$ or $2,184 / \mathrm{mm} .^{3}$ ). A barium meal and follow-through were normal, and at paracentesis abdominis 15 pints of amber fluid were aspirated and contained $98 \%$ eosinophils and 5 g. $\%$ protein. A repeat aspiration a few days later contained $64 \%$ eosinophils.

Ten days after admission he developed more oedema of the anterior abdominal wall, sacrum and legs, and a few days later had a bout of diarrhoea and vomiting associated with fever. The gastrointestinal symptoms soon settled but a low-grade fever persisted. Lower abdominal tenderness with some rebound was found together with resistance over the right upper quadrant. A presumptive diagnosis of Hodgkin's disease was made. However, he made a spontaneous recovery and when followed up as an out-patient his only complaint was occasional upper abdominal discomfort after meals with nausea and vomiting.

He remained in remission for four years, when, on 3 July 1961, having suppressed anxiety over his mother who refused to see a doctor for a lump in her breast, he presented with a recurrence of abdominal distension and loose stools. Examination again revealed ascites and bilateral hydrothorax. Pleural aspiration showed a cellular exudate with $90 \%$ eosinophils. W.B.C.s numbered $5,000 / \mathrm{mm}^{3}$ (eosinophils $35 \%, 1,750 / \mathrm{mm}^{3}$ ). A skin and muscle biopsy was normal.

A barium meal and follow-through (Figs. 2-3) showed 'marked evidence of small bowel thickening and narrow- 
ing with delayed transit suggestive of Crohn's disease'. At this stage a diagnosis of eosinophilic granuloma ('eosinophilic Crohn's disease') was made with eosinophilic polyserositis. He was treated initially with A.C.T.H., 30 units daily, and then changed to a reducing dose of prednisone. He showed dramatic improvement and was discharged one month later without symptoms and having one bowel action daily. On his discharge the white cell count was $9,000 / \mathrm{mm}^{3}$ with $2 \cdot 5 \%$ eosinophils $\left(225 / \mathrm{mm}^{3}{ }^{3}\right.$ ).

He was last seen on 12 December 1964 and said he had been very well. $\mathrm{He}$ is at present taking prednisone, 2.5 mg. b.d., and is still working for the same building firm. His social circumstances remain unchanged.

CASE 3 M.S., a male orthodox Jew, in 1964 (July), aged 14 , presented with a three-week history of diarrhoea, passing blood and mucus, and upper abdominal, praecordial and left shoulder tip pain made worse on breathing.

On examination he had a pericardial rub and a left pleural effusion, findings confirmed by electrocardiography and radiography. Sigmoidoscopy showed typical active ulcerative colitis, and was confirmed by barium enema of which the main feature was 'saw-tooth' ulceration of the descending and pelvic colon.

The blood count showed eosinophilia. W.B.C.s numbered 15,800/mm. ${ }^{3}$ (eosinophils 28\%, 4,424/mm. ${ }^{3}$ ) and $13,500 / \mathrm{mm}^{3}$ (eosinophils $18 \%, 2,430 / \mathrm{mm} .{ }^{3}$ ).

Stools contained no ova. All these symptoms remitted when the patient was given prednisone and terramycin.

After two months' observation as an out-patient these were tailed off.

He was readmitted in October 1964 febrile and with an exact recurrence of the previous chest and shoulder pain relieved by sitting forward. Pericarditis and a left pleural effusion were again present.

W.B.C.s numbered $8,600 / \mathrm{mm}^{3}$ (eosinophils $11 \%$, $946 / \mathrm{mm}^{3}{ }^{3}$ ). The E.S.R. (Westergren) was $83 \mathrm{~mm}$. in the first hour. Pleural fluid did not show eosinophilia. Faeces again were negative for ova. A toxocara skin test was negative, a Casoni test was negative, and virus studies were negative. A skin and muscle biopsy was negative. During the period of investigation treatment was withheld apart from analgesics, and fever, pleurisy, and pericarditis persisted.

A diagnosis of polyarteritis nodosa concomitant with ulcerative colitis was suspected and he was given A.C.T.H. with immediate remission of symptoms and signs.

The following past and family history seems relevant. He first passed blood and mucus per rectum in 1950 aged $2 \frac{1}{2}$ months. With substitution of National dried milk for breast feeding he recovered, but every spring and summer until he was 9 years old he had diarrhoea and rectal bleeding, a clear-cut diagnosis of ulcerative colitis being made at the age of 3 . Relapses in 1955 and 1956 were especially severe, necessitating admission to the paediatric wards for some weeks when he required blood transfusion for severe anaemia. Because of increasing introspection on the part of the child and tensions with the parents routine hospital admissions were stopped. (His mother herself had had ulcerative colitis since the age of 13.) It seemed that for the following four years relapses were short and mild.

The family history which now emerged was strongly

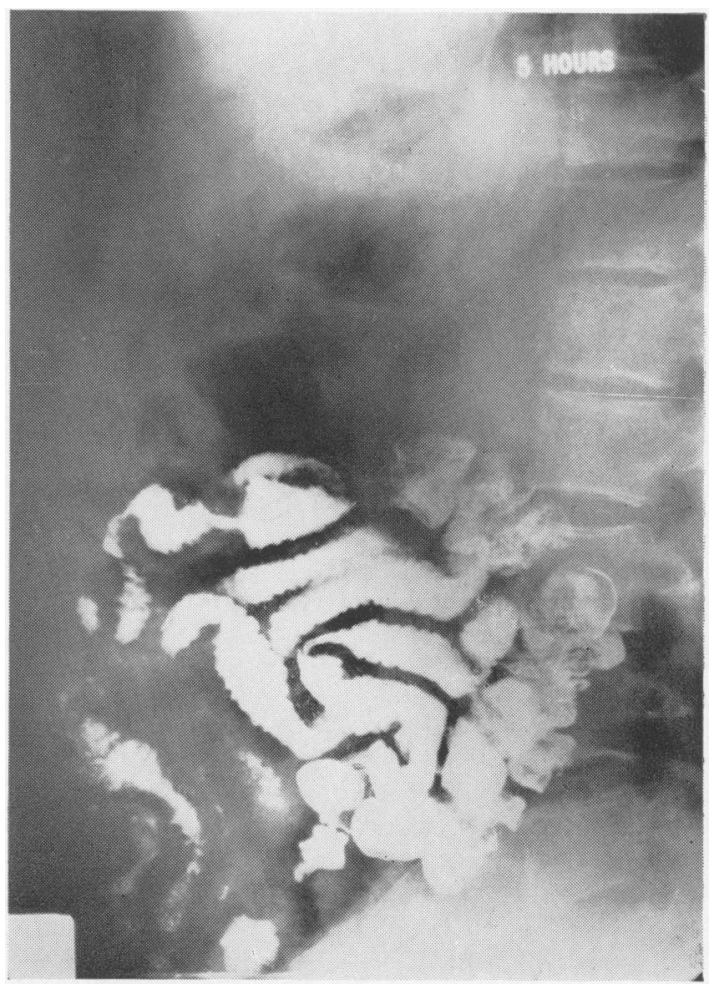

FIG. 2. Five-hour film.

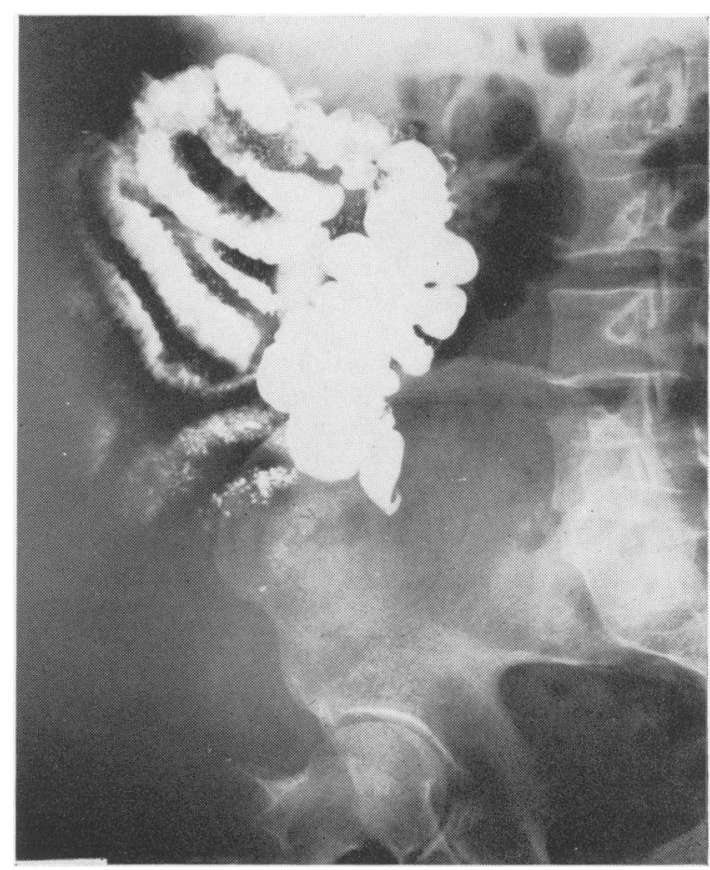

FIG. 3. Seven-hour film. 
allergic on both sides, and we suspect significant in view of the age of onset of the patient's colitis and the subsequent eosinophilic reaction, pleurisy, and pericarditis. The patient was the eldest of four children. His youngest sister, aged 18 months, was found to be very sensitive to fish. Vomiting and facial oedema occurred after helping to scale sprats. Now aged 6 she still cannot enter fish shops without a reaction, and a single scale provokes intense oedema.

His paternal grandmother had urticaria requiring admission to hospital, and she was sensitive to white fish. A paternal uncle had bronchial asthma. His maternal grandmother and aunt both had urticaria requiring hospital admission with no recognized food allergy. A maternal aunt's son (cousin) had bronchial asthma. Neither side of the family eat shell fish, which is forbidden to orthodox Jews.

Tragically the patient's colon became available for examination after his suicide in October 1965, while in hospital receiving exclusion diets in search of an allergic factor. It showed ulcerative colitis but no eosinophilic infiltration. However, he had recently had A.C.T.H. for a severe relapse occasioned by the stress of his mother's colectomy in July 1965 . The mother's colon also showed ulcerative colitis with a suggestion of early precancerous change but no evidence of Crohn's disease or eosinophilic granuloma.

Enough has been said to indicate that the psychological ramifications here were relevant and intense, but brevity prohibits fuller treatment of them.

\section{DISCUSSION}

CLINICAL PRESENTATION The presentation of gastrointestinal eosinophilic granuloma is variable and depends on the site and extent of the lesions, the presence of submucosal or serosal involvement, and of systemic allergic reactions. Available reports demonstrate the great variation in the site and extent of the lesions.

Thus gastrointestinal eosinophilic granuloma have been reported in the pharynx (Brunner, 1951), stomach (Kaijser, 1937; Barrie and Anderson, 1948; Vanek, 1949; Moloney, 1949; Nunes, 1950; Spencer, Comfort, and Dahlin, 1950; Booher and Grant, 1951; Doniach and Mckeown 1951; Barnett and Kazmann 1952; Fennel, 1952; Ruzic, Dorsey, Huber, and Armstrong, 1952; Helwig and Rainer, 1953; Orr, Miller, and Russell, 1954; Judd, Civin, and McIlhany, 1955; Swarts and Young, 1955; McCune, 1955; Rigler, Black, and Hebbel, 1956; Fischer, 1956; Smith, 1956; Toole and Moschopoulos, 1959; Kuipers et al., 1960a, 1960b; Voorhuis and Eijler, 1961; Salm, 1965; Russell and Evangeloe, 1965), duodenum (Barrie and Anderson, 1948; Herrera and de la Guardia, 1948; Moloney, 1949; Spencer et al., 1950; Swarts and Young, 1955; Toole and Moschopoulos, 1959; Széchy and Földvári, 1962; Ashby et al., 1964; Russell and Evangelou, 1965), jejunum (Kaijser, 1937; Moloney, 1949; Polayes and Krieger, 1950; Fennel, 1952; Taccani, 1952; Orr et al., 1954; Ferrier and Davis, 1957; Hollmotz and Stepan, 1963), ileum (Herrera and de la Guardia, 1948; Marek, 1954; Unnewehr and Ohrt, 1954; Virshup and Mandelburg, 1954; Swarts and Young, 1955; Pound, 1956; Urban and Lenczyk, 1956; Koneman, Sawyer, and Lubchenko, 1959; Cox, 1960; Kuipers et al. 1960a, 1960b; Bauab, 1961; Fossgreen, 1962), appendix (Stemmerman, 1961), caecum (Swarts and Young, 1955), colon (de Santis, 1954; Bauab, 1961), and rectum (Steger and Noto, 1953).

Distribution within the gastrointestinal tract may be seen at a glance from Table I. Males have predominated over females in the proportion of $3: 2$ and the peak incidence is in the sixth decade, the age range being 14 to 84 . Forty per cent of reported cases have occurred in the stomach, commonly presenting with epigastric pain and/or vomiting.

\section{TABLE I}

\begin{tabular}{lcc}
\multicolumn{1}{c}{ DISTRIBUTION OF LESIONS IN GASTROINTESTINAL TRACT } \\
$\begin{array}{l}\text { Polypoid } \\
\text { Granulomata }\end{array}$ & $\begin{array}{c}\text { Infiltrative } \\
\text { Granulomata }\end{array}$ \\
\hline $\begin{array}{l}\text { Pharynx } \\
\text { Stomach }\end{array} \quad 1$ & - \\
$\quad$ Body & 1 & 6 \\
Antrum & 3 & 30 \\
Small bowel & 14 & 5 \\
$\quad$ Duodenum & 1 & 7 \\
$\quad$ Jejunum & 1 & 28 \\
$\quad$ Ileum & 3 & 16 \\
Appendix & - & - \\
Caecum & 3 & - \\
Colon & 5 & 1 \\
Rectum & 1 & 5 \\
Gall bladder & - & 5 \\
Peritoneum & - & 104 \\
Generalized diffuse & - & \\
Total number of cases & 32 & \\
Total number of lesions & 122 &
\end{tabular}

Case 1 eventually showed the classical radiological appearance of eosinophilic granuloma of the pyloric antrum although the diagnosis was not made at the time. Some cases have been discovered accidentally (Rigler et al., 1956). In the small bowel the symptoms are usually those of intermittent subacute obstruction as in case 2, although perforation is described (Russell and Evangelou, 1965). The polypoid granulomata may present as acute intussusception (Marek, 1954; Koneman et al., 1959; Cox, 1960; von Bogsch and Feher, 1963), granuloma of the appendix with acute abdominal pain, or without symptoms (Stemmerman, 1961) and a distal ileal lesion may mimic acute appendicitis (Kuipers et al., 1960b).

Serosal involvement seems to lead to eosinophilic ascites as in case 2 and in the cases described by 
Harley et al. (1959); case 3 of Swarts and Young (1955), and the case described by Sison et al. (1947), whilst eosinophilic pleural exudates suggest systemic involvement (case 2).

PATHOLOGY Confusion persists because we do not yet know whether gastrointestinal eosinophilic granuloma in its various forms represents a common host response with all the variability that that entails, or whether two or more quite separate aetiological processes are at work.

There is, however, remarkable similarity on microscopy of all eosinophilic granulomata of the bowel. There may be hypertrophy and hyperplasia of the intestinal muscle wall (probably due to chronic intestinal obstruction), and in addition oedema of the muscle wall and serosa. Throughout the muscle wall there is infiltration by sheets of eosinophils maximal in the perivascular regions. Cases are described with medial necroses of serosal vessels (Harley et al., 1959 , cases 1 to 4) suggesting necrotizing angiitis of the hypersensitivity type. Increased collagen tissue may occur, especially in the muscle bundles. Local lymph nodes may be infiltrated with eosinophils and adjacent blood vessels may show eosinophil cuffing. Mucosal ulceration may also occur (Ortmayer, Balkin, and Humphreys, 1946; Vanek, 1949; Nunes, 1950; Koneman et al., 1959).

AETIOLOGY It has been stated that systemic allergic reactions are the exception in eosinophilic granuloma of the bowel. A study of reported cases, however, shows 20 cases $(16 \%)$ with an undoubted allergic history. A further 14 cases had an eosinophilia of more than $10 \%$ (greater than $400 / \mathrm{mm}^{3}$.) so that a total of 34 cases $(28 \%)$ had presumptive evidence of allergy. Case 1 had undoubted allergy and was a poultry farmer as were the two patients described by Orr et al. (1954). Of some interest is the fact that he developed acute oedema of the glottis while eating chicken. Case 2 had an intense eosinophilic polyserositis whilst case 3 gave a remarkable family history of allergy.

It is widely accepted that the allergic state is heavily influenced byemotional tension, and is indeed the subject of an extensive literature. The cases we report support this. Cases 2 and 3 possessed the personality profile described for Crohn's disease and ulcerative colitis, but case 1 did not, having many of the attributes of the duodenal ulcer patient. This invites the suggestion that the site of eosinophilic granuloma may be determined in this way.

Swarts and Young (1955) considered that the polypoid eosinophilic granuloma was essentially a separate condition from the infiltrating type. Systemic allergy is rare in the polypoid form. Only one definite report was found in the literature and this was a case with a gastric polypoid granuloma with diffuse bowel changes as well (Spencer et al., 1950). Host responses are so variable that we do not take this as sufficient evidence to separate the two forms.

There is evidence that numerous substances may act as allergens, notably neoarsphenamine and intestinal parasites. Various foods may be incriminated in individual cases following the effect of elimination diets. The mode of action is obscure at present but Gear (1955) showed that extracts of liver from rabbits with neoarsphenamine poisoning evoked significant antibody responses. Several workers have shown the effect of other allergens on the gastrointestinal tract.

Waltzer, Gray, Straus, and Livingstone (1938) and Waltzer (1941) produced experimental hypersensitivity in the monkey bowel and demonstrated histological changes similar to eosinophilic granuloma. Hansen and Simonsen (1938) reported a patient in whom hypersensitivity to egg albumen presented with gastric disorders, pain, vomiting, urticaria, and angioneurotic oedema. After giving egg albumen, pylorospasm, swelling, and increased rugal markings were found in the stomach.

Afendoulis and Gülzow (1937) produced acute gastritis with hyperacidity in sensitized dogs after intravenous injection of horse serum. Later (1943) they reported allergic gastritis and urticaria following the use of quinine in a patient known to be allergic to this drug, and in a similar case with arthralgia following antipyrine. It seems likely that immunological mechanisms will be found to account for these variable host responses. Thus the recent report of 14 cases of active ulcerative colitis with increased total serum complement is of interest (Fletcher, 1965). Complement inactivation may also be at fault in some cases of angioneurotic oedema (Donaldson and Evans, 1963). We foresee a greatly increased percentage of cases attributed to allergy with greater awareness of the potentialities of food allergy and improved methods of identifying it.

Intestinal parasites have been incriminated in several reports. Afendoulis (1948) reported five cases of acute allergic gastritis associated with amoebiasis of the colon. Kuipers et al. (1960a, 1960b) reported cases from Holland where herrings were eaten unsalted before the Dutch government introduced legislation. These cases all presented as an acute abdomen and were found to have eosinophilic granulomata of the bowel associated with a larval roundworm normally found in the North Sea herring. Exact identification of the larval roundworm is difficult at present (Williams, 1965). Members of the Gnathostomidae, Ancylostomidae, Ascaridae, 
and Anisakidae can also cause eosinophilic granuloma (Freeman, 1964). Stemmerman (1961) studied 16 cases of eosinophilic granulomata of the appendix. Six out of 10 patients who had their faeces examined for parasites had Strongyloides stercoralis infestation. Thiel (1962) showed that the larvae of Anisakis (normally found in the herring) caused a slight tissue reaction in the bowel of experimentally infested rabbits when they penetrated the bowel wall. When another larva penetrated near the first site an inflammatory response resembling that seen in humans was observed.

Our view is that eosinophilic granuloma of the gastrointestinal tract represents part of a systemic allergic response to one of a number of non-specific allergens. The nature of the response is primarily vascular and represents one end of a spectrum of tissue changes ranging from necrosis and granuloma formation to angiitis. Classical polyarteritis nodosa and the arteritis of rheumatoid arthritis and dermatomyositis represent the other end of the spectrum with arteritis and minimal granulomatosis. Eosinophilic granuloma should probably be grouped with Wegener's granulomatosis, lethal mid-line granuloma, and Loeffler's syndrome.

TREATMENT Surgery is indicated for obstructive lesions and in general for cases presenting as an acute abdomen where the diagnosis is usually in doubt. Ferrier and Davis (1957) used A.C.T.H. for a case of diffuse eosinophilic granuloma of the jejunum diagnosed at laparotomy. A course of $\mathbf{4 0}$ units daily for two weeks caused immediate and complete relief of pain and diarrhoea. A recurrence of symptoms one month later was again treated successfully by a further course. Our case 2 was similarly treated with A.C.T.H. followed by oral steroids. The result was equally dramatic and after three years there has been no recurrence of symptoms.

We wish to thank Drs. Trevor Shaw and Basil Morson for histological reports and Mr. Maurice Turney for the photographs.

\section{REFERENCES}

Afendoulis, T. C. (1943). Uber einen Fall von Gastritis allergica. Dtsch. med. Wschr., 69, 398.

- (1948). Observations on acute allergic gastritis. Amer. J. dig. Dis., $15,90-92$.

- , and Gülzow, M. (1937). Die allergisch-hyperergische Gastritis. Tierexperimentelle Untersuchungen. Z. ges. exp. Med., 104, 167-181.

Alarcón-Segovia, D., and Brown, A. L., Jr. (1964). Classification and etiologic aspects of necrotizing angiitides. Proc. Mayo Clin., 39, 205-222.

Ashby, B. S., Appleton, P. J., and Dawson, I. (1964). Eosinophilic granuloma of gastro-intestinal tract caused by herring parasite Eustoma rotundatum. Brit. med. J., 1, 1141-1145.

Barnett, L. A., and Kazmann, H. A. (1952). Gastric granuloma with eosinophilic infiltration. Amer. J. Surg., 84, 107-110.

Barrie, H. J., and Anderson, J. C. (1948). Hypertrophy of the pylorus in an adult with massive eosinophil infiltration and giant-cell reaction. Lancet, 2, 1007-1009.

Bauab, E. G. (1961). Eosinophilic granuloma of the gastrointestinal tract. Massive intestinal haemorrhage caused by multiple localization of the caecum, ascending colon, transverse colon and the ileum. Bol. Soc. Cirug. B. Aires, 45, 276-290.

Bogsch, A., and Fehér, E. (1963). Wiederoolt auftretende Dünndarminvagination bei eosinphoilem Granulom. Z. ges. inn. Med., 18, 1132-1143.

Booher, R. J., and Grant, R. N. (1951). Eosinophilic granuloma of the stomach and small intestine. Surgery, 30, 388-397.

Brunner, H. (1951). Eosinophilic granuloma of mouth, pharynx, and nasal passages. Oral Surg., 4, 623-640.

Cox, J. S. T. (1960). Submucosal ileal granuloma with eosinophilic infiltration and intussusception. Brit. J. Surg., 48, 149-150.

Donaldson, V. H., and Evans, R. R. (1963). A biochemical abnormality in hereditary angioneurotic edema. Absence of serum inhibitor of C'l-esterase. Amer. J. Med., 35, 37-44.

Doniach, I., and McKeown, K. C. (1951). A case of eosinophilic gastritis. Brit. J. Surg., 39, 247-250.

Fennel, E. A. (1952). Eosinophilic linitis plastica. Proc. Staff Meet. Straub Clin. (Honolulu), 18, 69-78.

Ferrier, T., and Daves, N. (1957). Eosinophilic infiltration of stomach and small intestine. Med. J. Aust., 1, 789-791.

Fletcher, J. (1965). Serum complement levels in active ulcerative colitis. Gut, 6, 172-175.

Fossgreen, J. (1962). Eosinophile granulomatosis. (In German.) Acta path. microbiol. scand., 56, 143-154.

Fischer, H. G. (1956). Das eosinophile Granulom des Magens. Chirurg, 27, 516-519.

Freeman, R. S. (1964). Studies on responses of intermediate hosts to infection with Taenia crassiceps (Zeder 1800) (Cestoda). Canad. J. Zool., 42, 367-385.

Gear, J. (1955). Auto-antibodies and the hyper-reactive state in the pathogenesis of disease. Acta med. scand., suppl. 306, 39-55.

Hansen, K., and Simonsen, M. (1937). Röntgenologische Beobachtung und Darstellung der allergischen Gastritis und des allergischen Pylorospasmus. Röntgenpraxis, 9, 145-151.

Harkavy, J. (1941). Vascular allergy: pathogenesis of bronchial asthma with recurrent pulmonary infiltrations and eosinophilic polyserositis. Arch. intern. Med., 67, 709-734.

Harley, J. B., Glushien, A. S., and Fisher, E. R. (1959). Eosinophilic peritonitis. Ann. intern. med., 51, 301-308.

Helwig, E. B., and Rainer, A. (1953). Inflammatory fibroid polyps of the stomach. Surg. Gynec. Obstet., 96, 355-367.

Herrera, J. M., and de la Guardia, J. (1948). Un raro caso de eosinofilia gastro-intestinal motivadora de un cuadro organico de estenosis pilorica. Arch. Hosp. (Santo Tomas), 3, 19-34.

Hollmotz, O., and Stepan, Z. (1963). Submukózni granulom tenkého Střeva $s$ eozinofilni infiltraci. (Submucous granuloma of the small intestine: eosinophil infiltration.) C s. Rentgonol., 17, 65-68.

Judd, C. S. Jr., Civin, W. H., and Mcllhany, M. L. (1955). Eosinophilic granuloma of the stomach. Gastroenterology, 28, 453-457.

Kaijser, R. (1937). Zur Kenntnis der allergischen Affektionen des Verdauungskanals vom Standpunkt des chirurgen aus. Langenbecks Arch. klin. Chir., 188, 36-64.

Koneman, E. W., Sawyer, K. C., and Lubchenko, A. E. (1959). Eosinophilic granuloma of the ileum. Arch. Surg., 78, 923-927.

Kuipers, F. C. van Thiel, P. H., and Roskam, E. T. (1960a). Eosinofiele flegmone van de dunne darm, veroorzaakt door een niet aan het lichaam van de mens aangepaste worm. Ned. T. Geneesk., 104, 422-427.

-, van Thiel, P. H., Rodenburg, W., Wielinga, W. J., and Roskam, R. T. (1960b). Eosinophilic phlegmon of the alimentary canal caused by a worm. Lancet, 2, 1171-1173.

McCune, W. S., Gusack, M., and Newman, W. (1955). Eosinophilic gastroduodenitis with pyloric obstruction. Ann. Surg., 142, $510-518$.

Marek, S. (1954). Eosinofiní granulom tenkého střeva. (Eosinophilic granuloma of small intestine). Cas. Lék. čes., 93, 484-485.

Mock, H. E. (1931). Infective granuloma. Surg. Gynec. Obstet., 52, 672-689.

Moloney, G. E. (1949). Pyloric hypertrophy with eosinophil infiltration. Lancet, 1, 412

Nunes, M. A. (1950). Granuloma (granuloblastoma) gástrico submucoso com eosinófilos. Gaz. méd. port., 3, 751-759.

Orr, I. M., Miller, A. A., and Russell, J. Y. W. (1954). Eosinophilic infiltration of the stomach and bowel. Postgrad. med. J., 30, 485-493. 
Ortmayer, M., Balkin, R., and Humphreys, E. (1946). Chronic, erosive, granulomatous, atrophic gastritis. Gastroenterology, 6, 298-301.

Polayes, S. H., and Krieger, J. L. (1950). Eosinophilic granuloma of the jejunum. J. Amer. med. Ass., 143, 549-551.

Pound, A. W. (1956). Personal communication. Cited by Ferrier and Davis (1957).

Rigler, L. G., Blank, L., and Hebbel, R. (1956). Granuloma with eosinophils: benign inflammatory polyps of the stomach. Radiology, 66, 169-176.

Russell, J. Y. W., and Evangelou, G. (1965). Eosinophilic infiltration of the stomach and duodenum complicated by perforation Postgrad. med. J., 41, 30-33.

Ruzic, J. P., Dorsey, J. M., Huber, H. L., and Armstrong, S. H., Jr. (1952). Gastric lesion of Loefflers syndrome. J. Amer. med. Ass., 149, 534-537.

Salm, R. (1965). Gastric fibroma with eosinophilic infiltration. Gut, 6, 85-91.

de Santis, M. (1954). Granuloma eosinofilo del cieco. Policlinoco, Sez prat., 61, 1521-1527.

Sherman, F. E., and Moran, T. J. (1954). Granulomas of stomach. 1. Response to injury of muscle and fibrous tissue of wall of human stomach. Amer. J. clin. Path., 24, 415-421.

Sison, A. B. M., Dioisio, S. A., Silva, J. A., and Chavez, P. C. (1947) Allergic peritonitis: report of a case. J. Amer. med. Ass., 134, 1007-1010.

Smith, M. J. (1956). Gastric granuloma with eosinophilic infiltration. Radiology, 66, 177-180.

Spencer, J. R., Comfort, M. W., and Dahlin, D. C. (1950). Eosinophilic infiltration of the stomach and bowel associated with pyloric obstruction and recurrent eosinophilia. Gastroenterology, 15, 505-513.

Steger, C., and Noto, L. (1953). Granuloma of the rectum of essinophilic type. Acta chir. patav., 9, 339-344.

Stemmermann, G. N. (1961). Eosinophilic granuloma of the appendix.
A study of its relation to Strongyloides infestation. Amer. clin. Path., 36, 524-531.

Swarts, J. M., and Young, J. M. (1955). Primary infiltrative eosinophilic gastritis, enteritis, and peritonitis. Gastroenterology, 28, 431-452.

Széchy, M., and Földvári, G. (1962). A nyombél eosinophil granulomája. (Eosinophilic granuloma of the duodenum.) Orv. Hetil., 103, 501-502.

Taccani, C. (1952). Granuloma eosinofilo dell'ileo. Chirurgia (Milano), 7, 454-460.

Thiel, P. H. van. (1961). Réconciliation entre les conceptions concernant la biologie de l'Entamoeba histolytica, en rapport avec la perturbation de l'équilibre entre l'homme et le parasite par le traitement médical. Bull. Soc. Path. exot., 54, 824-829.

Toole, H. J., and Moschopoulos, A. N. (1959). Eosinophilic granuloma of the gastro-intestinal tract: report of two cases. Brit. J. Surg., 46, 445-448.

Unnewehr, F., and Ohrt, H. (1954). Eosinophiles Granulom des Dünndarms als Ursache für einen Ileus. Zbl. Chir., 79, 91-93.

Urban, A. and Leńczyk, M. (1956). W sprawie tzw. granuloma eozynophilicum jelita biodrowego. (So-called eosinophilic granuloma of the ileum. Pat. pol., 7, 307-311.

Vanek, J. (1949). Gastric submucosal granuloma with eosinophilic infiltration. Amer. J. Path., 25, 397-411.

Virshup, M., and Mandelberg, A. (1954). Eosinophilic granuloma of the gastro-intestinal tract. Ann. Surg., 139, 236-240.

Voorhuis, F. J., and Eijlers, W. (1961). Een ontsekingstumor van de maag, waarschijnlijk veroorzaakt door de haringworm. Ned. T. Geneesk., 105, 2542-2545.

Walzer, M., Gray, I., Straus, H. W., and Livingstone, S. (1938). Studies in experimental hypersensitiveness in the rhesus monkey: IV. The allergic reaction in passively locally sensitized abdominal organs. J. Immunol., 34, 91-95.

- (1941). Allergy of the abdominal organs. J. Lab. clin. Med., 26, 1867-1877.

Williams, H. H. (1965). Roundworms in fishes and so-called 'herringworm' disease. Brit. med. J., 1, 964-967. 